NOTE

\title{
First reported cases of intersex (ovotestis) in the flatfish species dab Limanda limanda: Dogger Bank, North Sea
}

\author{
G. D. Stentiford* ${ }^{*}$ S. W. Feist \\ Centre for Environment, Fisheries and Aquaculture Science (CEFAS), Barrack Road, The Nothe, Weymouth, Dorset DT4 8UB, UK
}

\begin{abstract}
This paper provides the first report of the intersex (ovotestis) condition in the flatfish species dab Limanda limanda. Specimens presenting the condition were collected from the North Dogger Bank in the North Sea during the United Kingdom National Marine Monitoring Programme in 2003. Two of the individuals collected (14.3\% of the males sampled) presented externally as males but upon histological examination were seen to contain both male and female gonadal tissues. Previtellogenic oocytes were suspended within a matrix of spermatogonia and spermatocytes. One of the specimens also presented dilated testicular follicles filled with masses of mature spermatozoa. The significance of this finding in the United Kingdom's sentinel offshore monitoring species is discussed with relation to potential offshore effects of exposure to endocrine disrupting chemicals (EDCs).
\end{abstract}

KEY WORDS: Flatfish · Endocrine disruption · Limanda limanda · Ovotestis · Ovary · Testis · Reproduction

Resale or republication not permitted without written consent of the publisher

\section{INTRODUCTION}

In recent years a significant proportion of research into the biological effects of contaminants in the aquatic environment has been devoted to the study of endocrine disrupting chemicals (EDCs) of anthropogenic origin. EDCs have been widely reported to impair fertility, development, growth and metabolism in a range of animal groups (see Colborn et al. 1996). The effects of exposure of fish to such compounds include disturbed maturation and degeneration of the gonads, elevated concentrations of vitellogenin (egg yolk protein) in the plasma of male fish and the presence of intermediate or 'intersex' gonads (Gimeno et al. 1996). Using histological analysis, fish with the intersex condition are seen to possess oocytes within their normal testicular matrix (Sharpe 1997, Bateman et al. 2004).

Until the early 1990s intersex had only rarely been described from fish in the wild (Jafri \& Ensor 1979, Slooff \& Kloowijk-Vandijk 1982, Blachuta et al. 1991).
However, the condition has now been detected in several wild freshwater and migratory species, including roach Rutilus rutilus (Jafri \& Ensor 1979, Purdom et al. 1994, Jobling et al. 1998), gudgeon Gobio gobio (van Aerle et al. 2001), barbel Barbus plebejus (Vigano et al. 2001), chub Leuciscus cephalus (Minier et al. 2000), bream Abramis brama (Slooff \& Kloowijk-Vandijk 1982), white perch Morone americana (Kavanagh et al. 2002), stickleback Gasterosteus aculeatus (authors' pers. obs.), coregonids (Mikaelian et al. 2002), grayling Thymallus thymallus (Blachuta et al. 1991) and Atlantic salmon Salmo salar (authors' pers. obs.). Furthermore, detection of elevated prevalences of intersex in some estuarine and marine species such as the European flounder Platichthys flesus (Allen et al. 1999), Japanese flounder Pleuronectes yokohamae (Hashimoto et al. 2000), bothid flounder Bothus pantherinus (Amaoka et al. 1974), common eel Anguilla anguilla (Peters et al. 2001) and viviparous blenny Zoarces viviparus (Matthiessen et al. 2000, Stentiford et al. 2003) suggest that the effects of anthropogenic 
EDCs extend beyond inland river systems to coastal waters. With the exception of the reports of plasma vitellogenin and ovotestis in male Mediterranean swordfish Xiphias gladius (Fossi et al. 2001 and De Metrio et al. 2003, respectively), little evidence has so far been presented on endocrine disruption in the offshore environment.

This study provides the first report of intersex in the United Kingdom National Marine Monitoring Programme's (NMMP) offshore sentinel flatfish species dab Limanda limanda. Two fish presenting the condition were present in a sample of 50 dab collected from the Dogger Bank, an NMMP sampling station in the central North Sea, during 2003. This discovery marks the first histologically confirmed case of intersex in a marine fish species collected from an offshore site.

\section{MATERIALS AND METHODS}

Dab Limanda limanda were captured using $30 \mathrm{~min}$ tows of a standard Granton trawl on the Northern

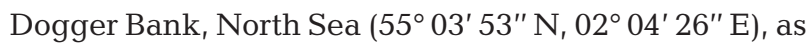
part of the NMMP, in July 2003. The sex, size (total length) and presence of external signs of disease were recorded for 50 fish using methodology specified by the International Council for the Exploration of the Sea (ICES) (Bucke et al. 1996). Following external disease assessment, fish were sacrificed by a blow to the head, followed immediately by severing of the spinal chord. Samples of liver, kidney, spleen and gonad were fixed in neutral buffered formalin for $24 \mathrm{~h}$ followed by transfer to industrial methylated spirit. Fixed samples were processed to wax in a vacuum infiltration processor using standard protocols. Sections were cut at 3 to $5 \mu \mathrm{m}$ on a rotary microtome and resulting tissue sections were mounted onto glass slides before staining with haematoxylin and eosin ( $\mathrm{H} \& \mathrm{E}$ ). Stained sections were analysed by light microscopy (Eclipse E800, Nikon) and digital images of histological features were obtained using the Lucia ${ }^{\mathrm{TM}}$ Screen Measurement System (Nikon). Histopathological description of the intersex (ovotestis) condition in dab follows that set out for the flounder Platichthys flesus by Bateman et al. (2004).

\section{RESULTS}

External visual examination revealed 14 male and 36 female dab from the sample collected at the North Dogger Bank site. Following histological preparation of gonadal tissue, 2 of the 14 males (apparent prevalence $14.3 \%$ ) contained gonads classified as ovotestis by Bateman et al. (2004). The case description for each specimen is given below.
Specimen 1 was a $26 \mathrm{~cm}$ (165 g) dab displaying the external diseases of hyperpigmentation (Grade 2) and the fin parasite Lepeophtheirus pectoralis. The kidney and spleen appeared histologically normal while the liver exhibited a basophilic focus of cellular alteration (FCA) and melanomacrophage aggregates (MMA). The gonad appeared as a predominantly mature male type consisting of large, dilated follicles filled with masses of mature spermatozoa (Fig. 1). Apparent spermatogonia and spermatocytes lined the connective membranes between follicles and, amongst these, small vacuoles were seen to contain maturing spermatids and mature spermatozoa. Also embedded within the spermatogonia and spermatocytes were oocytes at various stages of development (Fig. 2). The earliest stages contained small but pronounced eosinophilic nuclei with a homogenous basophilic cytoplasm. Larger oocytes also contained prominent nucleoli. The most mature stages observed were late perinuclear oocytes (Fig. 3). Although no oocytes were observed loose within the follicles, several were only partially embedded within the testicular parenchyma. Only 1 testicular lobe was assessed. The specimen was classified as Grade 1 according to the Ovotestis Severity Index (OSI) of Bateman et al. (2004).

Specimen 2 was a $21 \mathrm{~cm}$ (93 g) dab displaying the external diseases of hyperpigmentation (Grade 1) and an epidermal ulcer (Grade 1). The kidney and spleen appeared histologically normal while the liver exhibited a basophilic FCA, MMA and inflammation. The gonad appeared as a predominantly immature male type consisting of discrete testicular follicles containing spermatogonia and spermatocytes. Spermatozoa were present in small numbers. Oocytes were present in a focal area within the testis and, as in Specimen 1, were embedded within the matrix of spermatogonia and spermatocytes, occasionally within small vacuoles similar to those containing matures spermatozoa (Fig. 4). All of the oocytes were of immature development, containing a pronounced eosinophilic nucleus and a homogenous basophilic cytoplasm. Several of the oocytes appeared to be undergoing apoptosis, with condensation of chromatin within the nucleus and separation from their supporting matrix. Oocytes were only observed in 1 of the paired testicular lobes. The affected testicular lobe was classified Grade 1 according to OSI of Bateman et al. (2004).

\section{DISCUSSION}

The intersex condition is well described from the gonads of several wild gonochoristic teleost fish species inhabiting riverine and estuarine habitats. In several cases, the condition has been linked to the ambient presence of chemicals known to disrupt normal hormonal functioning of the host. On the other hand, re- 

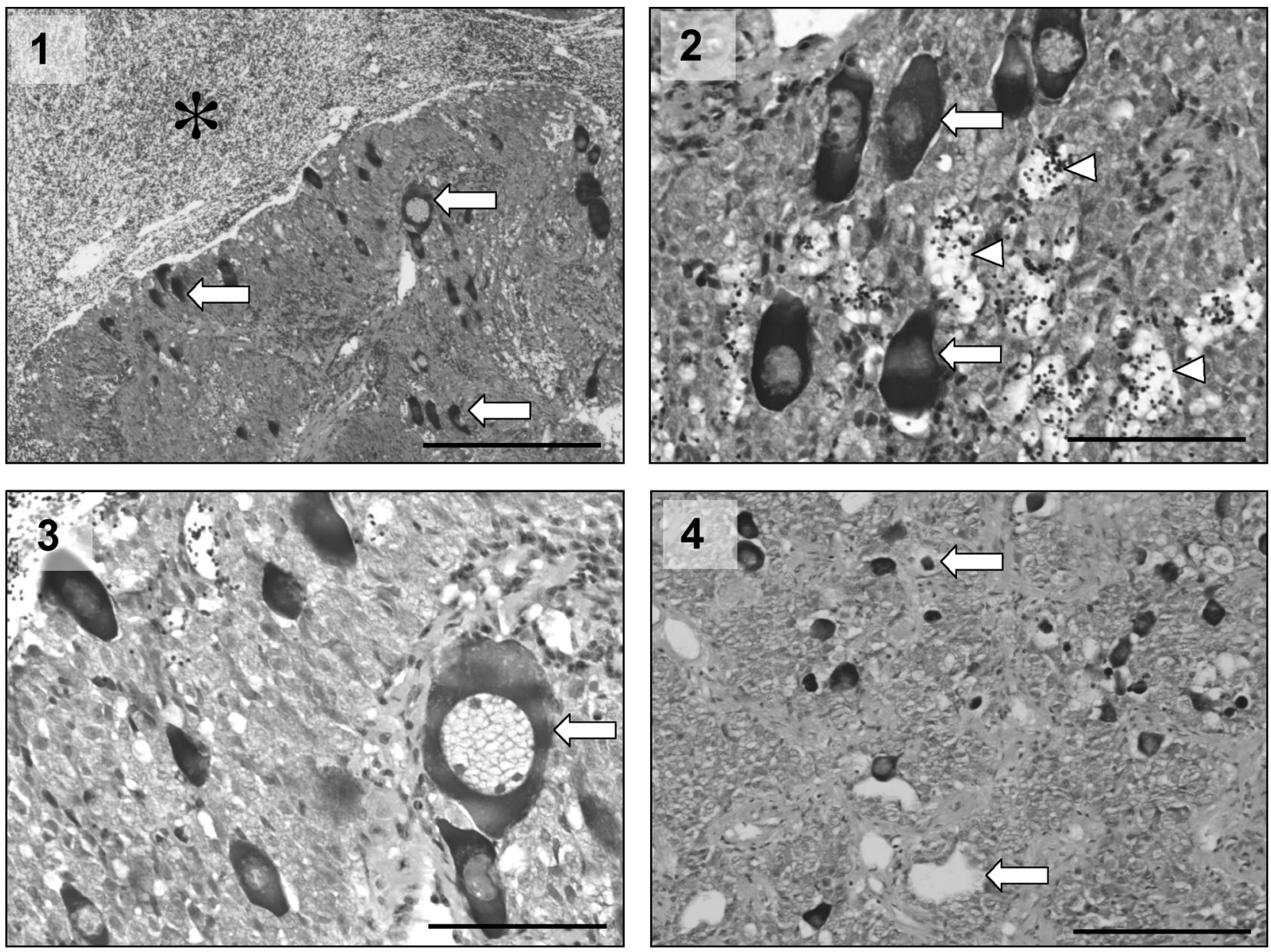

Figs. 1 to 4. Intersex (ovotestis) in the dab Limanda limanda. Fig. 1. Specimen 1. Masses of mature spermatozoa fill the dilated testicular follicles (asterisk) while pre-vitellogenic oocytes ( $\overline{\text { arrows }}$ ) are suspended in a matrix of spermatogonia and spermatocytes. Scale bar $=100 \mu \mathrm{m}$. Fig. 2. Specimen 1. Pre-vitellogenic oocytes (arrows) within spermatogonial matrix. Mature spermatozoa are present within vacuolated regions (arrowheads). Scale bar $=200 \mu \mathrm{m}$. Fig. 3. Specimen 1. Perinuclear stage oocytes (arrow) were the most mature stages observed. Scale bar $=50 \mu \mathrm{m}$. Fig. 4. Specimen 2. Predominantly testicular matrix consisting of follicles containing spermatogonia and spermatocytes. Pre-vitellogenic oocytes are suspended in follicle matrix and are occasionally present within vacuolated regions (arrows). Scale bar $=50 \mu \mathrm{m}$

ports of the condition in predominantly offshore species are rare. In the present study, we report the first cases of intersex in the marine flatfish species dab Limanda limanda. The current study follows an extensive survey of dab reproductive biology from the southern North Sea in the late 1970s. In these surveys, the intersex condition was not recorded (Htun-Han 1978a,b). Dab are utilised as the main offshore sentinel in the United Kingdom NMMP due to their abundance, relative ease of capture and their tendency to express biomarkers of contaminant exposure (including liver cancer) (Anon 2003, Feist et al. 2004). Intersex fish were only found at the North Dogger Bank site in the central North Sea. Fish captured at this site, along with those from nearby sites on this bank, have been shown previously to display relatively elevated levels of disease, including neoplastic lesions of the liver (Anon 2003). Further work is now required to compare contaminant burdens in sediment and fish tissue at these sites with those where such pathologies are not observed.

Since the intersex condition was not observed in dab captured from other NMMP sites during 2003, it could be proposed that those from the Dogger Bank site are displaying symptoms of exposure to EDCs. However, since hatchlings and juveniles are likely to inhabit different grounds to those where adults are sampled (Dipper 1987) and it is at these early life stages at which sex is determined (and at which disruption may occur) (Gimeno et al. 1997, Devlin \& Nagahama 2002), the presence of fish with the intersex condition at the North Dogger Bank site may not necessarily reflect the presence of EDCs at the site but rather their presence at sites where hatching and early growth occurs. Future studies should be directed towards the mea- 
surement of plasma vitellogenin in male fish in which intersex is found and to the histological analysis of juveniles. Studies of this kind would allow for assessment of potential endocrine disruption effects in adult fish and would also indicate the apparent prevalence of intersexuality in juveniles. Comparisons of the prevalence of the intersex condition in juvenile and adult fish of the same species may furthermore provide clarification on the population level effects of EDCs in the marine environment and on their long-term ecological effects on sensitive ecosystems. Coupled with studies on the population genetics of these species and the identification of specific spawning grounds for different adult stocks, the potential selective pressures imposed by endocrine disturbances may also be identified.

Acknowledgements. The authors would like to acknowledge the support of the Department of Environment, Food and Rural Affairs Marine and Waterways Division under contract AE003. Crown Copyright retained.

\section{LITERATURE CITED}

Allen Y, Scott AP, Matthiessen P, Haworth S, Thain JE, Feist SW (1999) Survey of estrogenic activity in United Kingdom estuarine and coastal waters and its effect on gonadal development of the flounder Platichthys flesus. Environ Toxicol Chem 18:1791-1800

Amaoka K, Nishikawa S, Tanaka N (1974) Sexual dimorphism and an abnormal intersexual specimen in the botid flounder Bothus pantherinus. Jpn J Ichthyol 21:16-20

Anon (2003) Monitoring of the quality of the marine environment, 2000-2001. Science Series; Aquatic Environment Monitoring Report 56. CEFAS, Lowestoft

Bateman KS, Stentiford GD, Feist SW (2004) A ranking system for the evaluation of intersex condition in European flounder (Platichthys flesus). Environ Toxicol Chem 23: 2831-2836

Blachuta J, Witkowski A, Kokurewicz B (1991) An hermaphrodite grayling, Thymallus thymallus (L.) from the Nysa Klodzka river (Lower Silesia, Poland). J Fish Biol 38: 955-957

Bucke D, Vethaak AD, Lang T, Mellergaard S (1996) Common diseases and parasites of fish in the North Atlantic: training guide for identification. ICES Tech Mar Environ Sci 19:1-27

Colborn T, Dumanoski D, Peterson Myers J (1996) Our stolen future. Abacus, London

De Metrio G, Corriero A, Desantis S, Zubani D and 7 others (2003) Evidence of a high percentage of intersex in the Mediterranean swordfish (Xiphias gladius L.). Mar Pollut Bull 46:358-361

Devlin RH, Nagahama Y (2002) Sex determination and sex differentiation in fish: an overview of genetic, physiological, and environmental influences. Aquaculture 208: 191-364

Dipper F (1987) British sea fishes. Underwater World Publications, London

Feist SW, Lang T, Stentiford GD, Koehler A (2004) Use of liver pathology of the European flatfish dab (Limanda limanda
L.) and flounder (Platichthys flesus L.) for monitoring. ICES Tech Mar Environ Sci 38:1-48

Fossi MC, Casini C, Ancora S, Moscatelli A, Ausilli A, Notarbartolo di Sciara G (2001) Do endocrine disrupting chemicals threaten Mediterranean swordfish? Preliminary results of vitellogenin and Zona radiata proteins in Xiphias gladius. Mar Environ Res 52:477-483

Gimeno S, Gerritson A, Bowmer T, Komen H (1996) Feminization of male carp. Nature 384:221-222

Gimeno S, Komen H, Venderbosch PWM, Bowmer T (1997) Disruption of sexual differentiaton in genetic male common carp (Cyprinus carpio) exposed to an alkylphenol during different life stages. Environ Sci Technol 31:2884-2890

Hashimoto S, Bessho H, Nakamura M, Iguchi T, Fujita K (2000) Elevated serum vitellogenin levels and gonadal abnormalities in wild male flounder (Pleuronectes yokohamae) from Tokyo Bay, Japan. Mar Environ Res 49:37-53

Htun-Han M (1978a) The reproductive biology of the dab Limanda limanda (L.) in the North Sea: seasonal changes in the ovary. J Fish Biol 13:351-359

Htun-Han M (1978b) The reproductive biology of the dab Limanda limanda (L.) in the North Sea: seasonal changes in the testis. J Fish Biol 13:361-367

Jafri SIH, Ensor DM (1979) Occurrence of an intersex condition in the roach Rutilus rutilus L. J Fish Biol 14:547-549

Jobling S, Nolan M, Tyler CR, Brightly G, Sumpter JP (1998) Widespread sexual disruption in wild fish. Environ Sci Tech 32:2498-2506

Kavanagh RJ, Balch GC, Kiparissis Y, Niimi AJ, Metcalfe CD (2002) Gonadal intersex in white perch (Morone Americana) from the Lower Great Lakes region. In: Conference on Great Lakes Research, Winnipeg, Canada, June 2002. International Association for Great Lakes Research, Ann Arbor, MI, p 64

Matthiessen P, Allen Y, Bignell J, Craft J and 8 others (2000) Studies of endocrine disruption in marine fish-progress with the EDMAR programme. ICES, Copenhagen

Mikaelian I, De Lafontaine Y, Harshbarger JC, Lee LLJ, Martineau D (2002) Health of lake whitefish (Coregonus clupeaformis) with elevated tissue levels of environmental contaminants. Environ Toxicol Chem 21:532-541

Minier C, Caltot G, Leboulanger F, Hill EM (2000) An investigation of the incidence of intersex fish in Seine-Maritime and Sussex regions. Analusis 28:801-806

Peters LD, Doyotte A, Mitchelmore CL, McEvoy J, Livingstone DR (2001) Seasonal variation and estradiol-dependent elevation of Thames estuary eel Anguilla anguilla plasma vitellogenin and comparisons with other United Kingdom estuaries. Sci Total Environ 279:137-150

Purdom CE, Hardiman PA, Bye VJ, Eno NC, Tyler C, Sumpter JP (1994) Estrogenic effects of effluent from sewage treatment works. Chem Ecol 8:275-285

Sharpe RM (1997) Do males rely on female hormones? Nature 390:447-448

Slooff W, Kloowijk-Vandijk E (1982) Hermaphroditism in the bream, Abramis brama (L.). J Fish Dis 5:79-81

Stentiford GD, Longshaw M, Lyons BP, Jones G, Green M, Feist SW (2003) Histopathological biomarkers in estuarine fish species for the assessment of biological effects of contaminants. Mar Environ Res 55:137-159

van Earle R, Nolan M, Jobling S, Christiansen LB, Sumpter JP, Tyler CR (2001) Sexual disruption in a second species of wild cyprinid fish (the gudgeon, Gobio gobio) in United Kingdom freshwaters. Environ Toxicol Chem 20:2841-2847

Vigano L, Arillo A, Bottero S, Massari A, Mandich A (2001) First observation of intersex cyprinids in the Po River (Italy). Sci Total Environ 269:189-194

Submitted: January 26, 2005 Accepted: May 21, 2005

Proofs received from author(s): September 16, 2005 